\title{
Seleksi Penerima Bantuan Langsung Tunai Menggunakan Profile Matching (Studi Kasus: Kelurahan Trikora Kota Jayapura)
}

\author{
Jim Lahallo ${ }^{1}$, Patmawati Hasan ${ }^{2}$, Rosiyati M.H. Thamrin ${ }^{3}$ \\ Program Studi Sistem Informasi \\ STIMIK Sepuluh Nopember Jayapura \\ Jayapura, Indonesia \\ e-mail: ${ }^{1}$ jim.lahallo@gmail.com, ${ }^{2}$ patmawatihasan@gmail.com, ${ }^{3}$ rosiyati.thamrin@yahoo.com
}

Diajukan: 20 Januari 2021; Direvisi: 19 Maret 2021; Diterima: 26 Maret 2021

\begin{abstract}
Abstrak
Bantuan langsung tunai pada kelurahan Trikora Kota Jayapura dilakukan oleh Lurah dimana pada pelaksanaannya, petugas akan melakukan survei terhadap masyarakat kelurahan. Kegiatan ini bertujuan untuk mengetahui kepastian domisili, kemampuan dan status penerima bantuan. Proses dilakukan menggunakan teknologi konvensional, seperti pencatatan survei di kertas dan penggunaan aplikasi pengolah kata atau tabel. Akibatnya, menimbulkan masalah seperti hasil seleksi menampilkan daftar penerima bantuan melebihi kuota dan munculnya warga tidak layak menerima. Permasalahan disebabkan karena tidak ada pengolahan hasil survei yang akuntable. Pada penelitian ini mengimplementasikan sistem pendukung keputusan menggunakan metode Profile Matching, sehingga kelurahan dapat menentukan profile target (karakteristik warga yang layak menerima bantuan) berdasarkan rata-rata tingkat kesejahteraan warga di kelurahan Trikora pada setiap periode penerimaan. Adapun kriteria yang digunakan antara lain: status penduduk, kemampuan warga, dan status penerima. Hasil pengujian sistem telah diuji 4 sample data untuk memudahkan pihak kelurahan dalam menilai relevansi hasil survei terhadap kenyataan kondisi warga. Berdasarkan kriteria yang digunakan dan diolah sistem mampu melaporkan daftar warga yang layak dan tidak layak menerima bantuan sebagai laporan penilaian sedangkan daftar penerimaan dilaporkan oleh sistem berdasarkan kuota penerimaan. Dari hasil pengujian data warga tersebut terdapat 2 warga dengan nilai yang sama (2.76) dan terpilih karena masih dalam batas kuota penerimaan.
\end{abstract}

Kata kunci: Bantuan langsung tunai, Sistem pendukung keputusan, Profile Matching, Dinas sosial.

\section{Abstract}

The direct cash assistance to Trikora village, Jayapura City, is carried out by the village head where in its implementation, the officer will conduct a survey of the village community. This activity aims to determine the certainty of domicile, capability and status of beneficiaries. The process is carried out using conventional technology, such as recording surveys on paper and using word or table processing applications. As a result, it raises problems such as the results of the selection showing a list of beneficiaries that exceed the quota and the emergence of unworthy residents. The problem is that there are no complaints about accountable survey results. This study implements a decision support system using the profile matching method, so that the sub-district can determine the target profile (characteristics of citizens who deserve assistance) based on the average level of welfare of residents in Trikora Village at each period of acceptance. The criteria used include: population status, citizen ability, and recipient status. The results of the system testing have been tested by 4 sample data to make it easier for the sub-district to assess the relevance of the survey results to the reality of the condition of the residents. Based on the criteria used and processed, the system is able to report the list of citizens who deserve and do not deserve to receive assistance as an assessment report, while the revenue list is reported by the system based on the revenue quota. From the results of the citizen data test, there were 2 residents with the same score (2.76) and were selected because they were still within the revenue quota limit.

Keywords: Direct cash assistance, Decision support systems, Profile matching, Social services. 


\section{Pendahuluan}

Perkembangan ilmu pengetahuan dan teknologi saat ini banyak mengalami perubahan di segala bidang, misalnya saja pada dunia pemerintahan dalam mengambil suatu keputusan. Sebagai lembaga pemerintahan yang berfungsi meningkatkan pelayanan kepada masyarakat untuk mencapai keadilan dan kesejahteraan, terutama dalam proses pengambilan keputusan agar tepat pada sasarannya, untuk itu diperlukan sebuah metode yang mendukung keputusan tersebut yang sesuai dengan permasalahan yang akan dipecahkan [1]. Dalam proses seleksi penerima bantuan langsung tunai oleh kelurahan Trikora dilakukan dengan beberapa tahapan. Tahapan tersebut antara lain: melakukan survei data penduduk, keluarga tidak mampu, dan status penerima. Hasil survei tersebut kemudian dicatat pada selembar kertas atau buku, kemudian berdasarkan hasil survei, kepala kelurahan menentukan warga yang layak menerima bantuan langsung tunai dengan kuota yang telah diterima dari Dinas Sosial, setelah proses penentuan selesai tahapan selanjutnya pengumpulan berkas administrasi warga calon penerima. Masalah keputusan yang timbul dari tahapan di atas adalah pengelolaan hasil survei. Di mana kelola saat ini cenderung menghasilkan menghasilkan hasil seleksi yang sering sama (warga yang menerima bantuan) sehingga sering terjadi kesalahan dalam penentuan warga yang harus diutamakan karena terbatasnya alokasi bantuan yang diberikan oleh Dinas Sosial. Profile Matching adalah sebuah mekanisme pengambilan keputusan dengan mengasumsikan bahwa terdapat tingkat variabel prediktor yang ideal yang harus dimiliki oleh subyek (warga kelurahan dengan nilai pada setiap kriteria keputusan) yang diteliti, bukannya tingkat minimal yang harus dipenuhi dan dimiliki tetapi kedekatan dengan profile target (kriteria layak menerima bantuan) [2]. Maka dari itu metode yang dipakai adalah Metode Profile Matching. Berdasarkan karakteristik tersebut, metode Profile Matching dipilih sebagai metode karena kepala kelurahan Trikora dapat menentukan seleksi penerima bantuan langsung tunai dengan kriteria kelayakan tertentu (penentuan profile target) yang disesuaikan dengan tingkat kesejahteraan warga pada suatu periode bantuan. Untuk mengatasi permasalahan di atas, maka dibangun sistem pendukung keputusan untuk seleksi penerima bantuan langsung tunai dengan menggunakan metode Profile Matching berbasis web studi kasus kantor kelurahan Trikora yang menggunakan kriteria penghasilan keluarga, status penduduk, keluarga tidak mampu dan status penerima kepala keluarga. Sistem ini mengimplementasikan model pengembangan waterfall, terkait tahapan-tahapan yang dilakukan hingga selesai.

Adapun beberapa penelitian terdahulu yang menjadi kajian pengembangan pada penelitian ini antara lain: pertama, sistem pendukung keputusan untuk menentukan penerima bantuan langsung tunai (BLT) dengan metode AHP, di mana pada penelitian ini menggunakan 5 kriteria keputusan (pendapatan, tanggungan, umur, dan kondisi perumahan) dengan AHP sebagai metode pendukung keputusannya di mana diperoleh nilai akhir tertinggi diperoleh KK1 $(0,2443)$, dan nilai terendah $(0,14866)$ untuk KK 5 [3], kedua, Sistem Pendukung Keputusan penentuan penerima Bantuan Langsung Tunai di kantor Kepala Desa Ngringo dengan menggunakan algoritma Simple Additive Weighting di mana pada penelitian menggunakan 4 kriteria antara lain interaktif, fleksibel, data kualitas, dan prosedur pakar dengan hasil tertinggi diperoleh Sumarno $(91,17)$ dan terendah dengan nilai 76,10 dari 10 data warga yang diuji [4], ketiga, Sistem Pendukung Keputusan penerima Bantuan Sosial Daerah Kutai Kartanegara menggunakan metode Electre, di mana pada penelitian ini mengelola beberapa program bantuan dan masing-masing program bantuan memiliki kriterianya sehingga hasil dari sistem merekomendasikan warga yang cocok hasil perhitungan berdasarkan Electre dengan program bantuan yang sedang dilakukan oleh pemerintah di mana hasil uji penelitian ini diperoleh nilai tertinggi adalah 11 dan nilai terendah adalah 0 , dari 30 data warga [5]. Sedangkan pada penelitian ini menggunakan Profile Matching sebagai metode pendukung keputusan dengan mengimplementasi 3 kriteria dengan sub kriteria antara lain: status penduduk (sub kriteria: asli warga kelurahan, tinggal lebih dari 5 tahun, dan asli Papua), keluarga tidak mampu (sub kriteria: jumlah anggota keluarga, dan penghasilan keluarga), dan status penerimaan (sub kriteria: pernah menerima bantuan, kelengkapan berkas administrasi, dan kepemilikan kendaraan).

\section{Metode Penelitian}

Waterfall sebagai salah satu model pengembangan sistem, dan digunakan pada penelitian untuk mengarahkan arah pelaksanaan penelitian terkait penyelesaian sistem pendukung keputusan ini yang juga dikombinasikan dengan tahapan-tahapan pelaksanaan metode Profile Matching sehingga sistem yang dihasilkan baik dan relevan. Adapun tahapan pengembangan sistem antara lain: perencanaan, analisis, desain, dan implementasi [6] seperti terlihat pada Gambar 1.

\subsection{Perencanaan}

Pada tahapan ini menemukan kebutuhan pengguna (pihak kelurahan) yang domain dengan melakukan survei dan observasi di lokasi penelitian untuk keperluan pembangunan persyaratan sistem 
seperti manajemen pengguna, pengolahan data (identifikasi kriteria, sub kriteria, dan data warga), di mana pembentukan kriteria dan sub kriteria berdasarkan aturan dan peraturan yang berlaku di wilayah kelurahan terkait mekanisme penyeleksian dan pemberian bantuan langsung tunai kepada warga.

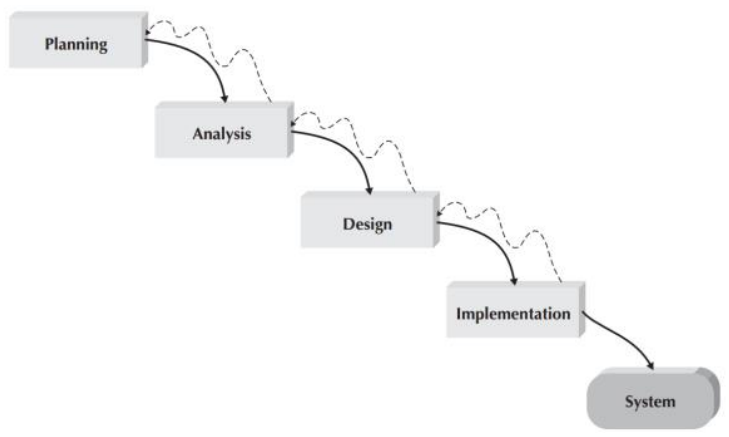

Gambar 1. Tahapan pengembangan sistem model waterfall.

\subsection{Analisis}

Untuk tahapan ini dari kebutuhan yang didapatkan, kemudian di analisis yang bersumber pada tahapan pelaksanaan profile matching [2], sistem sehingga diperoleh model sistem yang baik. Di mana tahapan-tahapan tersebut antara lain:

1. Memastikan kriteria.

2. Menentukan nilai bobot kriteria.

3. Memastikan sub kriteria.

4. Menentukan sub kriteria core dan secondary.

5. Membuat kategori penilaian sub kriteria.

6. Menentukan bobot nilai gap.

7. Menentukan profile target berdasarkan poin (6)

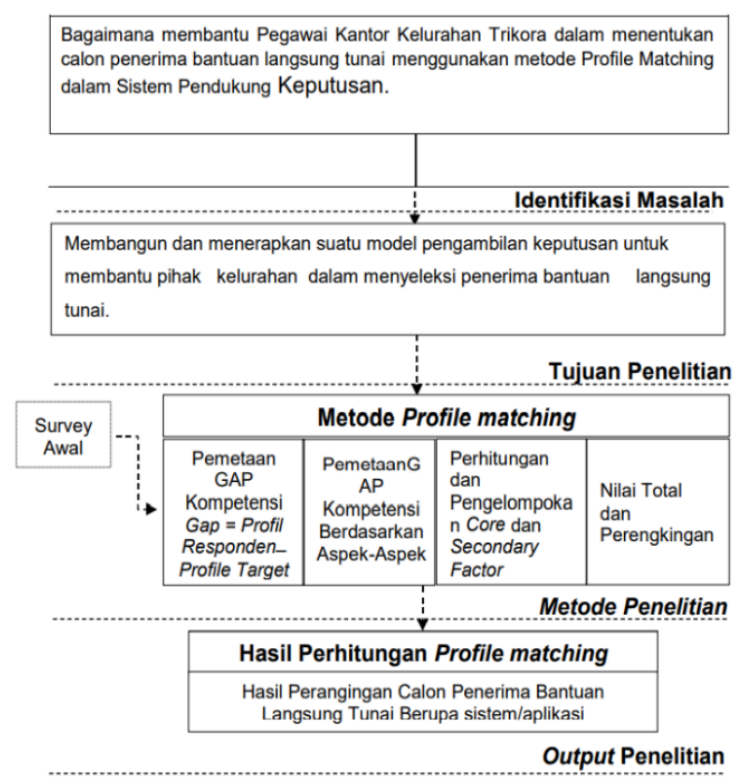

Gambar 2. Implementasi analisis terhadap tahapan pengembangan sistem.

Untuk itu wawancara perlu dilakukan dengan pejabat berwenang (Lurah) sehingga kebutuhan yang sudah didapatkan pada tahapan perencanaan dapat diperbaiki dan dipertanggungjawabkan pada tahapan pengembangan selanjutnya terutama untuk memodelkan perilaku sistem terkait pengolahan data. Selain itu tahapan analisis metode pendukung keputusan yang dilakukan antara lain:

1. Menghitung gap masing-masing alternatif.

2. Menghitung nilai akhir masing-masing alternatif.

3. Menghitung rangking dan solusi. 


\subsection{Desain}

Berdasarkan analisis kemudian, dilakukan desain sistem. Adapun desain yang dihasilkan pada penelitian ini berupa desain sistem dengan menggunakan Data Flow Diagram (DFD) level overview untuk memodelkan kesatuan luar terhadap aliran dan informasi dari dan ke sistem berdasarkan hasil analisis [7], selain itu juga dihasilkan permodelan data dalam bentuk Entity Relationship Diagram (ERD) [7]. Sehingga aliran data dan informasi relevan dengan data yang akan dikelola oleh sistem.

\subsection{Implementasi dan Pengujian}

Setelah desain diperoleh, selanjutnya proses implementasi sistem (sistem benar-benar dibangun) dilakukan. Pada tahapan ini juga implementasi basis data dilakukan menggunakan MySQL, Bahasa pemrograman yang dibangun adalah PHP untuk mengakses server web maupun basis data dan HTML untuk client [8]. Setelah itu dilakukan pengujian sistem dengan metode black box untuk memastikan fungsionalitas sistem sudah berjalan dengan baik atau belum [7]. Domain Fungsionalitas yang diuji adalah manajemen kriteria dan bobotnya, sub kriteria pada masing-masing kriteria beserta bobot dan bobot proses perhitungan oleh sistem berdasarkan aturan Profile Matching di mana pengujian ini dilakukan oleh tim peneliti seperti terlihat pada Tabel 1, di mana fungsi pengujian ini. Hal ini penting karena pengujian black box dapat memastikan keberhasilan fungsionalitas sistem sudah berjalan dengan baik [9].

Tabel 1. Hasil pengujian sistem dengan black box.

\begin{tabular}{|c|c|c|c|c|}
\hline Butir uji & Skenario uji & Hasil yang diharapkan & Hasil dari sistem & Keterangan \\
\hline \multirow[t]{4}{*}{ Penilaian } & $\begin{array}{l}\text { Mengisi data hasil survei, melalui } \\
\text { menu penilaian alternatif } \\
\text { berdasarkan sub kriteria untuk } \\
\text { masing-masing kriteria }\end{array}$ & $\begin{array}{l}\text { Tampil pesan berhasil atau } \\
\text { gagal. }\end{array}$ & $\begin{array}{l}\text { Sistem mampu } \\
\text { menampilkan pesan } \\
\text { berhasil atau gagal }\end{array}$ & Valid \\
\hline & $\begin{array}{l}\text { Melihat informasi hasil } \\
\text { perhitungan atau pengolahan hasil } \\
\text { survei }\end{array}$ & $\begin{array}{l}\text { Sistem mampu menampilkan } \\
\text { informasi hasil pengolahan } \\
\text { survei dengan nilai sesuai } \\
\text { rumus }\end{array}$ & $\begin{array}{l}\text { Sistem mampu } \\
\text { menampilkan dengan nilai } \\
\text { hasil sesuai rumus }\end{array}$ & Valid \\
\hline & $\begin{array}{l}\text { Melihat laporan penilaian akhir } \\
\text { yang diurutkan }\end{array}$ & $\begin{array}{l}\text { Sistem mampu menampilkan } \\
\text { laporan daftar warga yang } \\
\text { terurut dengan nilai akhir } \\
\text { sesuai rumus }\end{array}$ & $\begin{array}{l}\text { Sistem mampu } \\
\text { menampilkan nilai akhir } \\
\text { warga yang terurut dan } \\
\text { nilai sudah sesuai rumus }\end{array}$ & Valid \\
\hline & $\begin{array}{l}\text { Melihat daftar warga penerima } \\
\text { bantuan sesuai kuota yang telah } \\
\text { ditetapkan }\end{array}$ & $\begin{array}{l}\text { Sistem hanya melaporkan } \\
\text { warga yang layak menerima } \\
\text { bantuan berdasarkan urutan } \\
\text { dan kuota }\end{array}$ & $\begin{array}{l}\text { Sistem mampu menghasil } \\
\text { laporan daftar penerima } \\
\text { bantuan dari pertama } \\
\text { sampai terkecil sesuai } \\
\text { kuota yang telah } \\
\text { ditetapkan }\end{array}$ & Valid \\
\hline
\end{tabular}

\section{Hasil dan Pembahasan}

Bagian ini membahas hasil dari penelitian dan pada waktu yang sama juga memberikan pembahasan dan yang komprehensif. Hasil penelitian dapat disajikan menggunakan gambar, grafik, tabel, dan lainnya yang membuat pembaca dapat memahami hasil penelitian dengan mudah. Pembahasan dapat dibuat dengan menggunakan beberapa sub-bab.

\subsection{Kriteria dan Alternatif}

Untuk identifikasi kriteria serta alternatif menunjukkan bobot untuk masing-masing kriteria serta penentuan Core Factor (CF) dan Secondary Factor (SF) untuk masing-masing kriteria dapat dilihat pada Tabel 2.

Tabel 2. Kriteria dan bobot.

\begin{tabular}{lcllc}
\hline \multicolumn{1}{c}{ Kriteria } & Bobot $(\boldsymbol{\%})$ & Kode Sub & \multicolumn{1}{c}{ Sub kriteria } & Prioritas \\
\hline Status Penduduk & 40 & K1 & Warga kelurahan & CF \\
& & K2 & Tinggal > 5 tahun & CF \\
& & K3 & Orang asli Papua & SF \\
\hline Keluarga tidak mampu & 40 & S1 & Jumlah anggota keluarga & SF \\
& & S2 & Penghasilan keluarga & CF \\
\hline Status Penerimaan & 30 & T1 & Belum pernah menerima bantuan & CF \\
& & T2 & Kelengkapan berkas & CF \\
& & T3 & Tidak memiliki Kendaraan & SF \\
\hline
\end{tabular}




\subsection{Tabel Gap dan Profile Target}

Tabel gap yang digunakan pada sistem [10] ini dapat dilihat pada tabel 3. Di mana bobot nilai dibuat berdasarkan nilai indikator pada sub indikator di mana nilai indikator terdiri dari 1,2 dan 3 .

Tabel 3. Tabel gap.

\begin{tabular}{ccl}
\hline Selisih & Bobot nilai & \multicolumn{1}{c}{ Keterangan } \\
\hline 0 & 3 & Tidak ada selisih (Kompetensi sesuai dengan yang dibutuhkan) \\
\hline 1 & 2,5 & Kompetensi individu kelebihan 1tingkat \\
\hline-1 & 2 & Kompetensi individu kekurangan 1 tingkat \\
\hline 2 & 1,5 & Kompetensi individu kelebihan 2 tingkat \\
\hline-2 & 1 & Kompetensi individu kekurangan 2 tingkat \\
\hline
\end{tabular}

\subsection{Analisis Profile Matching}

Tabel 4 menunjukkan hasil survei dari warga yang dinilai berdasarkan nilai bobot pada masingmasing sub kriteria yang telah disepakati bersama pihak kelurahan.

Tabel 4. Profile alternatif.

\begin{tabular}{lcccccccc}
\hline \multirow{2}{*}{$\begin{array}{c}\text { Nama warga } \\
\text { (alternatif) }\end{array}$} & \multicolumn{3}{c}{ Status penduduk } & \multicolumn{2}{c}{ Keluarga tidak mampu } & \multicolumn{2}{c}{ Status Penerimaan } \\
\cline { 2 - 10 }$y$ & K1 & K2 & K3 & S1 & S2 & T1 & T2 & T3 \\
\hline Otis & 3 & 3 & 3 & 1 & 3 & 3 & 3 & 1 \\
\hline Joni & 2 & 2 & 3 & 3 & 3 & 3 & 3 & 3 \\
\hline Jemi Sesaray & 2 & 2 & 3 & 3 & 3 & 3 & 3 & 3 \\
\hline Samuel Wakris & 1 & 3 & 3 & 1 & 1 & 2 & 3 & 3 \\
\hline
\end{tabular}

Berdasarkan nilai profile pada Tabel 4 kemudian dihitung nilai gap sehingga mendapatkan nilai gap alternatif setiap warga (menghitung gap masing-masing alternatif) yang dinilai seperti pada Tabel 5 . Di mana persamaan yang digunakan adalah:

$$
\text { Nilai Gap }=\text { Profile alternatif }- \text { Profile target }
$$

Tabel 5. Nilai gap alternatif.

\begin{tabular}{lcccccccc}
\hline \multirow{2}{*}{$\begin{array}{c}\text { Nama warga } \\
\text { (alternatif) }\end{array}$} & \multicolumn{3}{c}{ Status penduduk } & \multicolumn{2}{c}{ Keluarga tidak mampu } & \multicolumn{2}{c}{ Status Penerimaan } \\
\cline { 2 - 9 }$y$ & K1 & K2 & K3 & S1 & S2 & T1 & T2 & T3 \\
\hline Otis & 1 & 0 & 0 & -2 & 0 & 0 & 0 & -2 \\
\hline Joni & 0 & -1 & 0 & 0 & 0 & 0 & 0 & 0 \\
\hline Jemi Sesaray & 0 & -1 & 0 & 0 & 0 & 0 & 0 & 0 \\
\hline Samuel Wakris & -1 & 0 & 0 & -2 & -2 & -1 & 0 & 0 \\
\hline
\end{tabular}

Kemudian dengan nilai pada Tabel 5 dilakukan perhitungan untuk mendapat nilai pada Tabel 6 . Di mana perhitungan dilakukan dengan persamaan:

Perhitungan nilai Core factor:

$$
N C F=\frac{\sum_{i}^{n}=1 N C}{\sum_{i}^{n}=1 I C}
$$

Perhitungan nilai Secondary factor:

$$
N S F=\frac{\sum_{i}^{n}=1 N S}{\sum_{i}^{n}=1 I S}
$$

Kemudian nilai akhir alternatif:

$$
\text { Nilai total }=60 \% N C F+40 \% N S F
$$

Tabel 6. Nilai akhir alternatif.

\begin{tabular}{lccc}
\hline Nama warga (alternatif) & Status penduduk & Keluarga tidak mampu & Status Penerimaan \\
\hline Otis & 2,8 & 2,4 & 2,2 \\
\hline Joni & 2,4 & 3 & 3 \\
\hline Jemi Sesaray & 2,4 & 3 & 3 \\
\hline Samuel Wakris & 2,6 & 1,6 & 2,7 \\
\hline
\end{tabular}


Sedangkan untuk mendapatkan pengurutan (Tabel 7) hasil Tabel 6 dihitung berdasarkan bobot yang diperoleh dari Tabel 2, dengan persamaan berikut:

Pengurutan $=40 \%$ status penduduk $+40 \%$ keluarga tidak mampu $+30 \%$ status penerimaan

Tabel 7. Hasil pengurutan nilai akhir

\begin{tabular}{lc}
\hline Nama warga (alternatif) & Nilai hasil \\
\hline Otis & 2,76 \\
\hline Joni & 2,76 \\
\hline Jemi Sesaray & 2,50 \\
\hline Samuel Wakris & 2,33 \\
\hline
\end{tabular}

\subsection{Desain Sistem}

\subsubsection{Arsitektur Sistem}

Sistem ini dibangun berbasis website online, sehingga memungkinkan petugas kelurahan dapat mengakses dari lokasi selain kantor kelurahan. Untuk itu pengguna sistem akan terhubung dalam jaringan komputer lokal dengan sistem dan data yang tersimpan pada online server (Gambar 3).

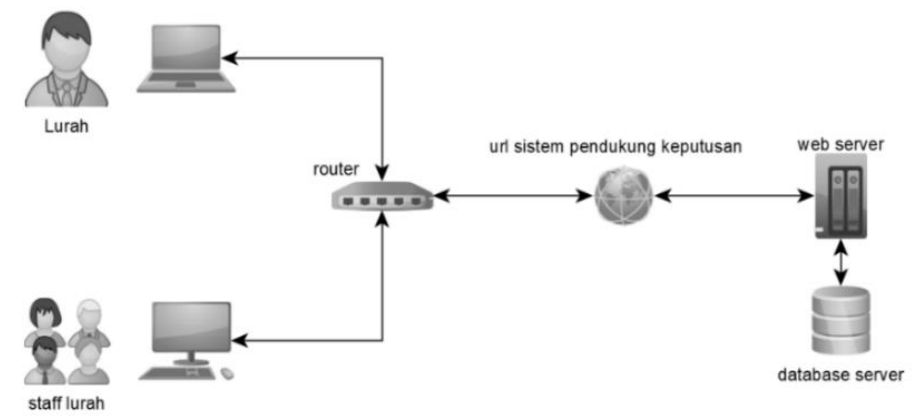

Gambar 3. Arsitektur sistem.

\subsubsection{Data Flow Diagram}

Kemudian memodelkan aliran data dan informasi dari sistem yang bersifat konteks (Gambar 4) dan detail konteks, untuk mengetahui domain proses yang dimiliki. Di mana kesatuan luar (pengguna sistem) yang terlibat adalah admin yang berfungsi untuk mengelola data kriteria dan alternatif sesuai metode Profile Matching dan data warga serta hasil survei petugas kelurahan terkait kriteria kelayakan yang diterapkan dalam sistem, serta lurah yang menerima hasil pengolahan data survei berupa laporan penilaian dan penerima bantuan.

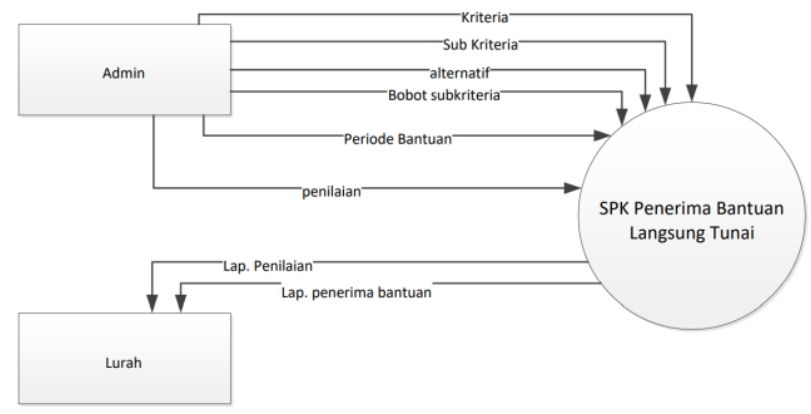

Gambar 4. Diagram konteks sistem.

Berdasarkan aliran data pada Gambar 4, didesain beberapa proses sebagai sub sistem untuk mengelola data periode, kriteria, sub kriteria, bobot kriteria, alternatif, dan penilaian yang dapat dilihat pada Gambar 5. Sehingga proses dan data dapat diolah untuk menghasilkan laporan penilaian dan penerimaan bantuan maupun informasi lainnya. 


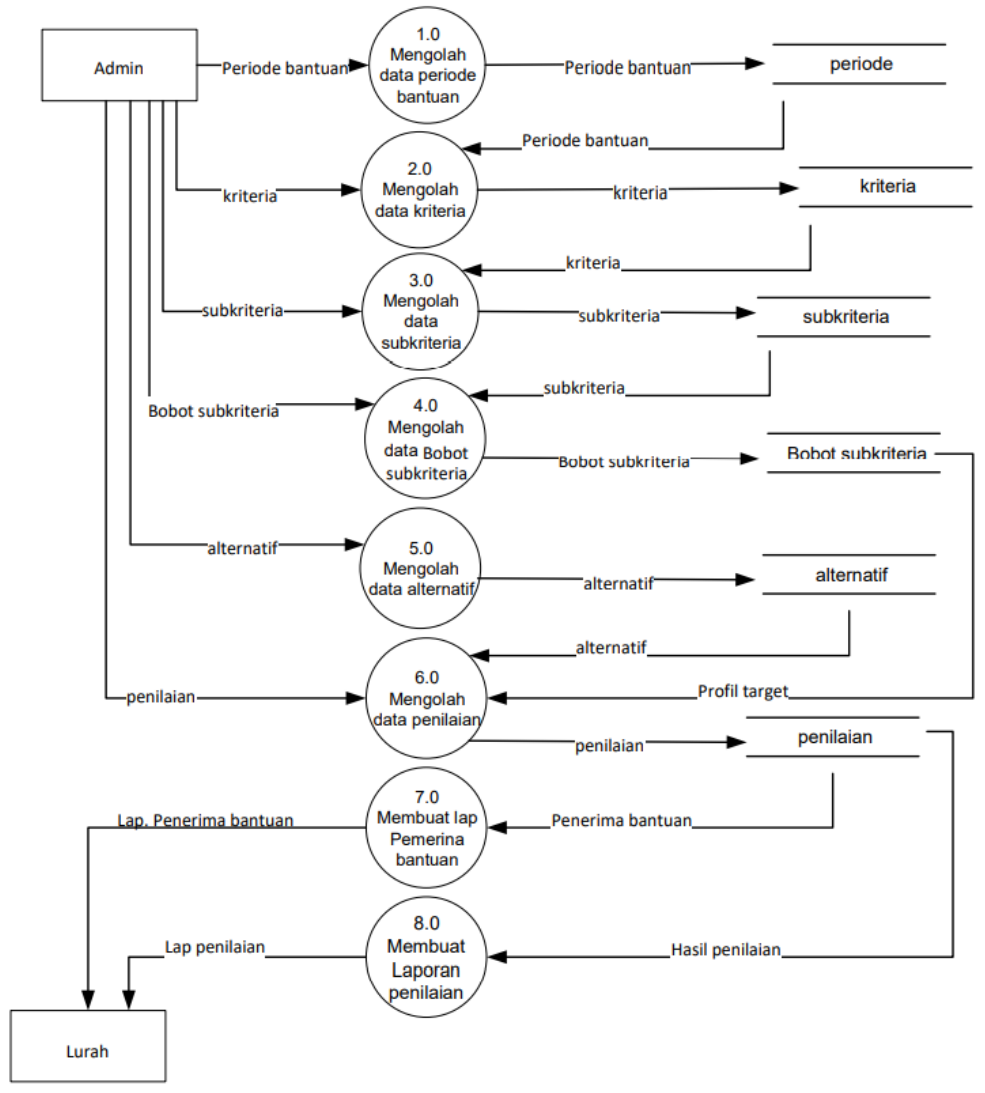

Gambar 5. Diagram overview sistem.

\subsubsection{Basis data}

Untuk konsep basis data, sistem ini memiliki 7 (tujuh) entitas yang akan diimplementasikan dalam bentuk Database Management Systems (DBMS) untuk keperluan pengolahan data sistem dapat dilihat pada Gambar 6.

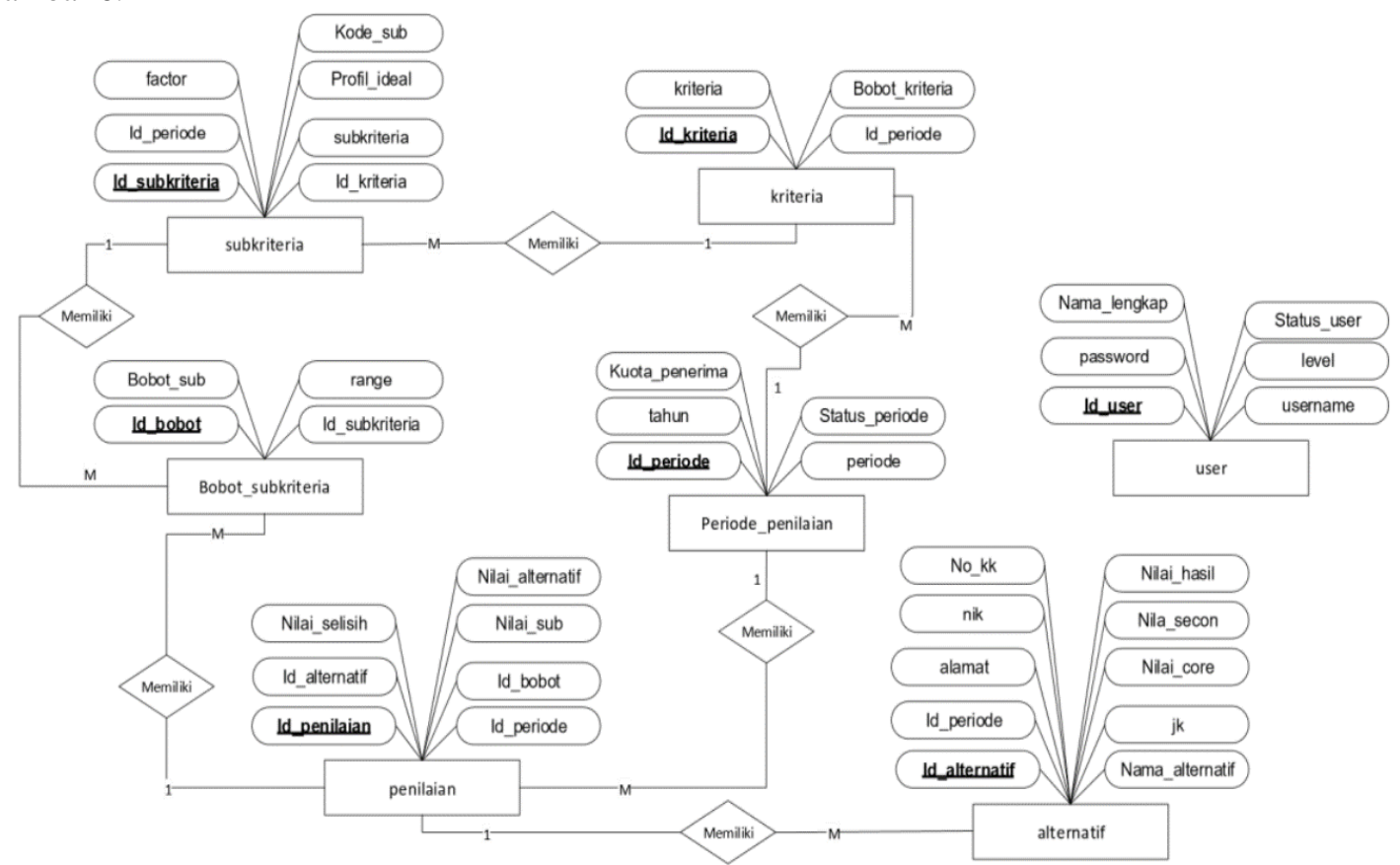

Gambar 6. Entity Relationship Diagram. 


\subsection{Hasil Pengujian Black Box}

Substansi pengujian yang disampaikan pada penelitian ini adalah pada informasi hasil perhitungan seperti dapat dilihat pada Tabel 8 .

Tabel 8. Hasil pengujian sistem dengan black box.

\begin{tabular}{clll}
\hline Butir uji & \multicolumn{1}{c}{ Skenario uji } & \multicolumn{1}{c}{ Hasil yang diharapkan } & \multicolumn{1}{c}{ Hasil dari sistem } \\
\hline Penilaian & $\begin{array}{l}\text { Mengisi data hasil survei, } \\
\text { melalui menu penilaian } \\
\text { alternatif berdasarkan } \\
\text { sukriteria untuk masing- } \\
\text { masing kriteria }\end{array}$ & Tampil pesan berhasil atau gagal. & $\begin{array}{l}\text { Sistem mampu menampilkan } \\
\text { pesan berhasil atau gagal }\end{array}$ \\
\cline { 2 - 4 } & $\begin{array}{l}\text { Melihat informasi hasil } \\
\text { perhitungan atau } \\
\text { pengolahan hasil survei }\end{array}$ & $\begin{array}{l}\text { Sistem mampu menampilkan } \\
\text { informasi hasil pengolahan survei } \\
\text { dengan nilai sesuai rumus }\end{array}$ & $\begin{array}{l}\text { Sistem mampu menampilkan } \\
\text { dengan nilai hasil sesuai rumus }\end{array}$ \\
\cline { 2 - 4 } $\begin{array}{l}\text { Melihat laporan penilaian } \\
\text { akhir yang diurutkan }\end{array}$ & $\begin{array}{l}\text { Sistem mampu menampilkan } \\
\text { laporan daftar warga yang terurut } \\
\text { dengan nilai akhir sesuai rumus }\end{array}$ & $\begin{array}{l}\text { Sistem mampu menampilkan } \\
\text { nilai akhir warga yang terurut } \\
\text { dan nilai sudah sesuai rumus }\end{array}$ \\
\cline { 2 - 4 } & $\begin{array}{l}\text { Melihat daftar warga } \\
\text { penerima bantuan sesuai } \\
\text { kuota yang telah } \\
\text { ditetapkan }\end{array}$ & $\begin{array}{l}\text { Sistem hanya melaporkan warga } \\
\text { yang layak menerima bantuan } \\
\text { berdasarkan urutan dan kuota }\end{array}$ & $\begin{array}{l}\text { Sistem mampu menghasil } \\
\text { laporan daftar penerima } \\
\text { bantuan dari pertama sampai } \\
\text { terkecil sesuai kuota yang telah } \\
\text { ditetapkan }\end{array}$ \\
& & & Valid \\
\end{tabular}

\subsection{Antar Muka Sistem}

Berikut beberapa menu (interface) sistem yang sangat penting digunakan atau diakses untuk menyelesaikan permasalahan pada penelitian ini. Antar muka tersebut antara lain untuk mengelola periode survei dan penerimaan bantuan tunai (Gambar 7).

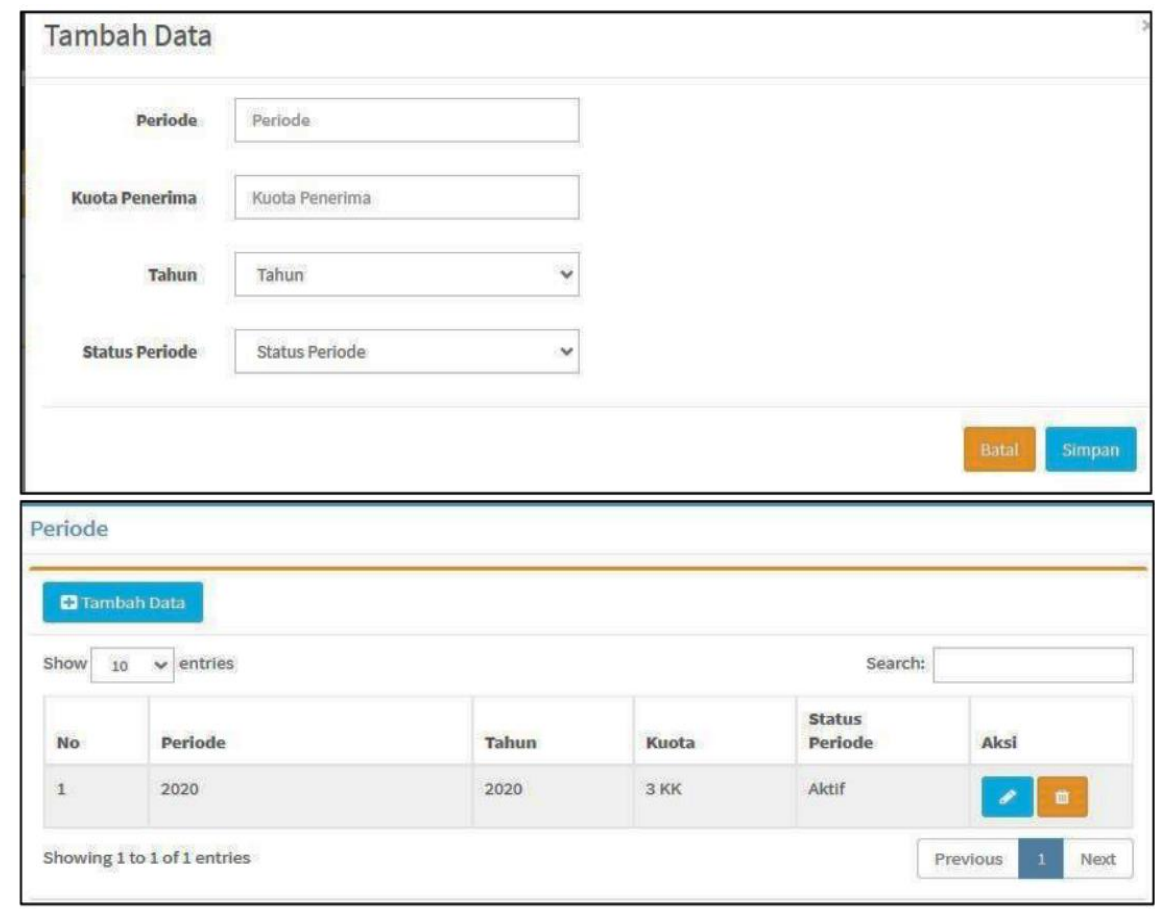

Gambar 7. Menu pengelolaan periode pemberian bantuan.

Sedangkan pengolahan data dan informasi hasil survei (penentuan nilai preferensi alternatif pada masing-masing kriteria) dapat dilihat pada Gambar 8. 


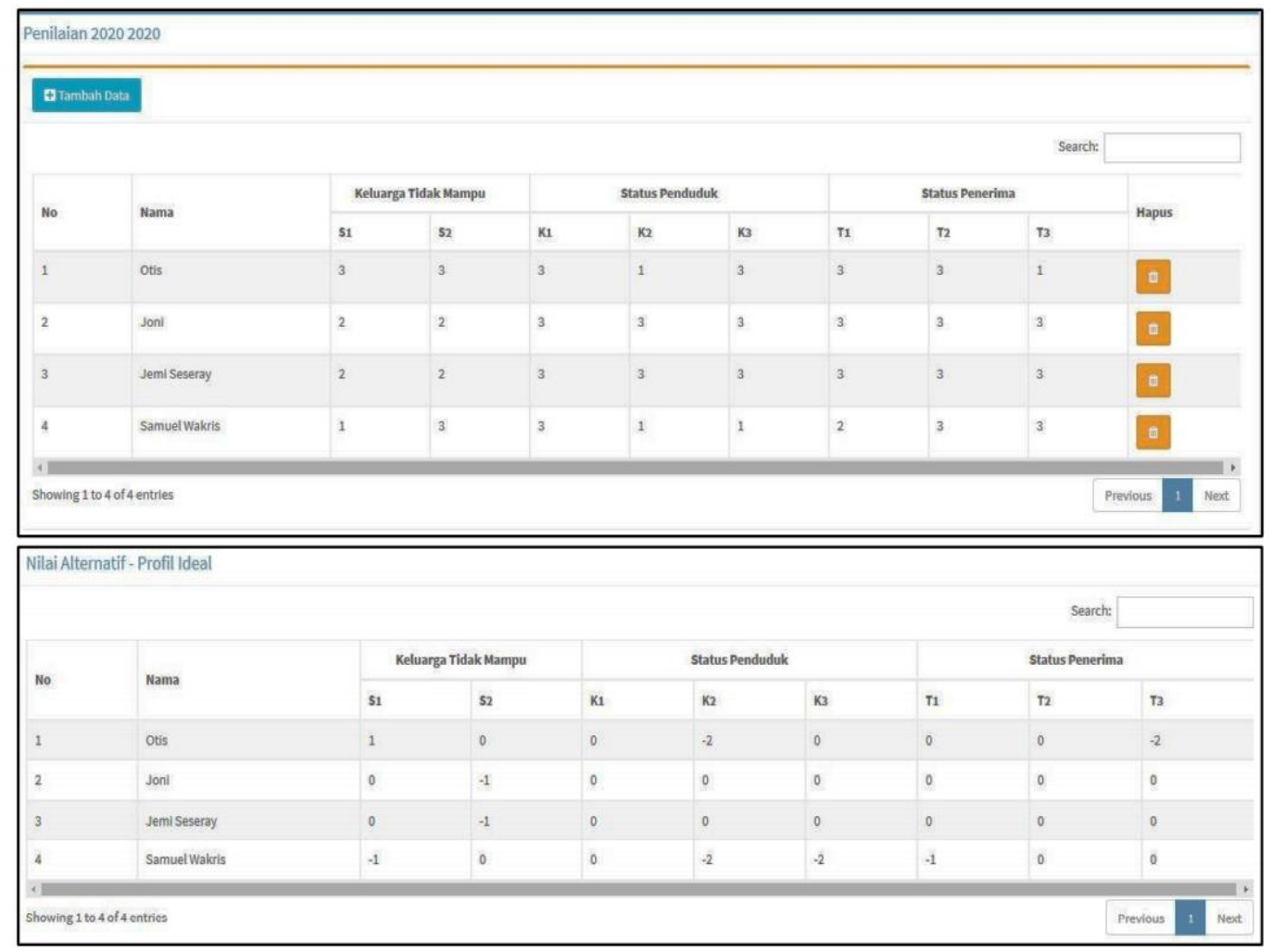

Gambar 8. Menu pengelolaan hasil survei warga.

Sedangkan informasi nilai hasil survei hasil perhitungan Profile Matching untuk keseluruhan warga yang disurvei dapat terlihat pada Gambar 9.

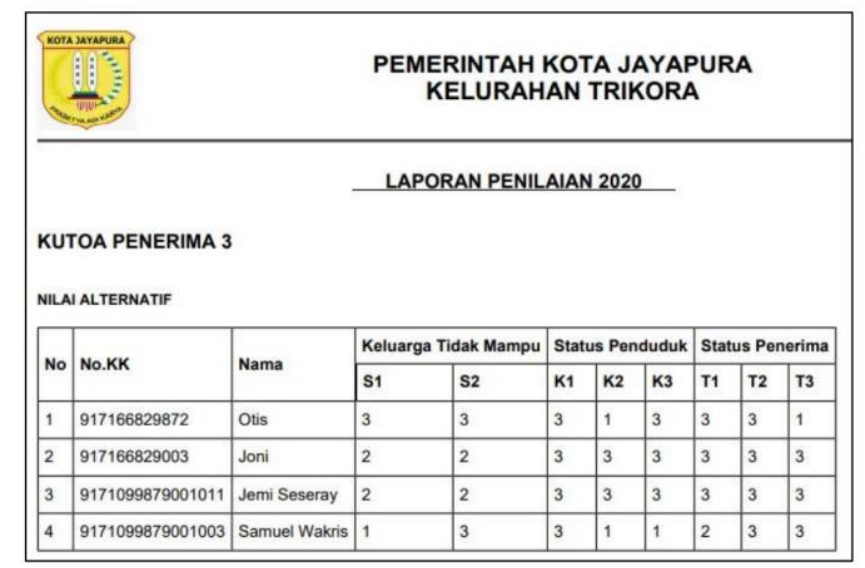

Gambar 9. Informasi survei.

Hasil akhir dari sistem ini adalah laporan penerimaan bantuan yang terurut dengan daftar yang ditampilkan sesuai kuota penerimaan bantuan (Gambar 10). 


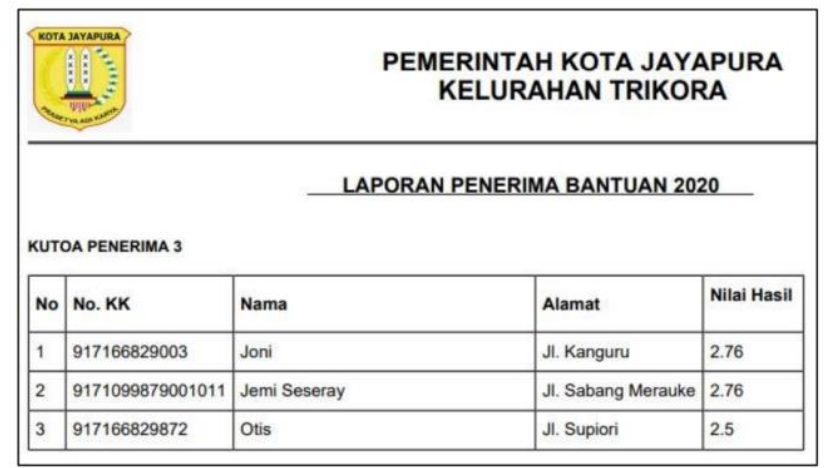

Gambar 10. Informasi penerima bantuan sesuai kuota terima

\section{Kesimpulan}

Berdasarkan analisis dan implementasi yang dilandaskan dari permasalahan untuk kasus pendukung keputusan yakni, seleksi penerima bantuan langsung tunai dari pihak kelurahan dapat disimpulkan, bahwa sistem ini mampu mengelola kriteria dan sub kriteria, gap, dan bobot kriteria maupun sub kriteria serta periode, yang memungkinkan pihak kelurahan dapat fleksibel dalam menggunakan atau menerapkan kriteria penyeleksian penerima pada setiap periode penerimaan sehingga akuntable perhitungan yang lebih teliti menggunakan metode Profile Mathcing dapat dilakukan dengan mudah. Selain itu penentuan indikator serta bobot pada kriteria, dan profile target mudah dipahami oleh pihak kelurahan dan hasil pengolahan dengan metode Profile Matching terkait relevansi hasil sistem dengan kondisi warga yang sebenarnya cukup baik.

Dengan jumlah warga yang tersebar serta geografis lingkungan domisili kelurahan Trikora, membuat sistem perlu dikembangkan untuk dapat diakses oleh warga terkait data demografi warga maupun beberapa data untuk keperluan sistem pendukung keputusan ini, sehingga kemudahan survei dan ketersediaan data akan membuat sistem ini jauh lebih akurat jika terjadi perubahan kriteria penyeleksian pada periode tertentu.

\section{Daftar Pustaka}

[1] D. K. Nugroho, "Pengembangan Dan Analisis Kualitas Sistem Pendukung Keputusan Sebagai Aplikasi Rekomendasi Pemilihan Beasiswa Di Perguruan Tinggi," Yogyakarta, 2018.

[2] Kusrini, Konsep dan Aplikasi Sistem Pendukung Keputusan. Yogyakarta: CV Andi Offset, 2017. Yogyakarta: Andi, 2017.

[3] R. Rahmona, I. P. Ningrum, and N. Ransi, "Sistem Pendukung Keputusan Untuk Menentukan Penerima Bantuan Langsung Tunai (Blt) Dengan Metode Analytical Hierarchy Process (Ahp) (Studi Kasus: Desa Sambuli, Kecamatan Abeli, Kota Kendari)," semanTIK, vol. 2, no. 1, pp. 257266, 2016.

[4] W. Wijayanti and S. T. Kustanto, "Sistem Pendukung Keputusan Penentuan Penerima Bantuan Langsung Tunai Di Kantor Kepala Desa Ngringo Dengan Menggunakan Algoritma Simple Additive Weighting," TIKomSIN, vol. 5, no. 1, pp. 20-26, 2017, doi: http://dx.doi.org/10.30646/tikomsin.v5i1.283.

[5] S. M. Maffirotin, M. Wati, and H. J. Setyad, "Sistem Pendukung Keputusan Penerima Bantuan Sosial Daerah Kutai Kartanegara Menggunakan Metode Electre,” JURTI, vol. 2, no. 1, pp. 9-16, 2018.

[6] R. M. Roth, B. H. Wixom, and A. Dennis, Systems Analysis and Design: An Object-Oriented Approach with UML 5th Edition, 5th ed. John Wiley \& Sons, Inc., 2012.

[7] A. S. Rosa and M. Shalauddin, Modul Pembelajaran Rekayasa Perangkat Lunak (Terstruktur Dan Berorientasi Objek). Bandung: Informatika : BANDUNG., 2011.

[8] R. R. Rerung, Pemrograman Web Dasar, 1st ed. Bandung: CV BUDI UTAMA, 2018.

[9] Umi Hanifah, Ronggo Alit, and Sugiarto, "Penggunaan Metode Black Box pada Sistem INformasi Surat Keluar Masuk," Scan, vol. 11, no. 2, pp. 33-39, 2016.

[10] F. Sari, Metode dalam pengambilan keputusan. Yogyakarta, 2018. 